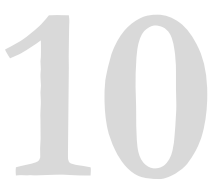

\title{
Extreme weather events in Small Island Developing States: Barriers to climate change adaptation among coastal communities in a remote island of Fiji
}

\author{
Stefano Moncada and Hilary Bambrick.
}

\begin{abstract}
Small Island Developing States (SIDS) are heavily affected by climate change, challenging their economic development as a result. Although research on SIDS under climate change is gaining momentum, lack of data and research capacity remains a major problem. Similarly, little is known about the interactions between poverty and responses to climate change.

In this chapter, we conduct a case study exploring how coastal communities on Rabi Island, Fiji, are affected by climate change. We identify reactive coping strategies to climate variability and change, and explore the extent to which these responses are conducive to climate change adaptation, adopting the Sustainable Livelihoods Framework and using the CRiSTAL tool. We find that the majority of shocks are of a climatic or weather-related nature. We also find that the communities tend to adopt sustainable coping strategies in response to climatic shocks. However, the increased frequency of such events, and the disproportionate burden on lower-income households, can act as barriers for the effective uptake of adaptation measures. This study can potentially inform local and regional policy as it pinpoints possible areas of intervention where strategic activities could support adaptation strategies to address climate change vulnerabilities.
\end{abstract}

Cite this article: Moncada, S. \& Bambrick, H. (2019): Extreme weather events in Small Island Developing States: Barriers to climate change adaptation among coastal communities in a remote island of Fiji. In: Klöck, C. \& Fink, M. (eds.): Dealing with climate change on small islands: Towards effective and sustainable adaptation? (pp. 217-247). Göttingen: Göttingen University Press. https://doi.org/10.17875/gup2019-1218 


\section{$1 \quad$ Introduction}

The evidence is increasing that Small Island Developing States (SIDS) are heavily affected by climate change, and that the challenge of economic development will be more difficult as a result (Nurse et al., 2014). Extreme weather events are detrimental to the livelihoods of many communities in SIDS (Cashman \& Nagdee, 2017; McCubbin, Smit, \& Pearce, 2015), and may push households to adopt unsustainable coping strategies in response, such as selling farm animals or working tools, thereby eroding assets and compromising future wellbeing (Takasaki, 2017). Although research on SIDS under climate change is gaining momentum, lack of data and research capacity remains a major problem, especially in poorer and more vulnerable island communities. Information on the effects on livelihoods, shortterm coping strategies, and long-term climate change adaptation (CCA) measures that are being implemented is scarce (Moncada, Briguglio, Bambrick, \& Kelman, 2018). Furthermore, existing poverty may delay uptake of effective CCA measures.

In this research the term 'coping strategy' is understood as the short-term reaction to shocks (Adger, Huq, Brown, Conway, \& Hulme, 2003), the immediate response to risks and stresses (Lashley \& Jonathan, 2013), and the ability to "just survive" (Smit \& Wandel, 2006). These coping strategies can be classified as sustainable when responses to hazards do not compromise present and future assets (Adger et al., 2011). On the other hand, unsustainable coping strategies can result in immediate responses that, by usually depriving households of key assets in an effort to cope, often fuelled by already low standards of living and higher deprivation levels (Porter, 2008), can affect future wellbeing (Brown, 2011).

Conversely, 'climate change adaptation' implies more long-term changes (Vogel, 1998). These changes can also be classified as sustainable, such as those actions that contribute to socially and environmentally sustainable development pathways, including social justice and environmental integrity (Eriksen et al., 2011), and tackle the drivers of vulnerability, for example by investing in improved education or better infrastructure (Lemos et al., 2013; Schipper, 2007). Unsustainable climate change adaptation, which can also be referred to as 'maladaptation', can happen when the actions undertaken do not address climate vulnerabilities, and where these actions impact adversely on, or increase, the vulnerability of other systems, sectors, or social groups (Barnett \& O'Neill, 2010, p. 211). Specific examples of unsustainable adaptation, among others, can be increasing emissions, vulnerability, or opportunity costs and reducing incentives or limiting choices for future generations (Juhola, Glaas, Linnér, \& Neset, 2016).

In this research we identify reactive coping strategies to climate variability and change, and explore the extent to which these responses are conducive to longterm CCA, adopting the Sustainable Livelihoods Framework (SLF) through the CRiSTAL tool. The SLF can be utilised to assess how livelihoods are diversified as part of a strategy to cope with shocks (Ellis, 1998). Examples of livelihood diversification include variation of income sources from farm to non-farm income 
(Paavola, 2008), agricultural diversification such as improved crop variety (Deressa, Hassan, \& Ringler, 2009), as well as migration by means of providing remittances (Konseiga, 2006).

We conduct a case study exploring how coastal communities on remote Rabi Island, situated off the east coast of Fiji's second largest island Vanua Levu, are affected by climate change. We aim to assess and better understand to what extent climatic or weather-related events may affect coastal communities, adding to a body of published case study/place-based knowledge on coastal communities of SIDS, which, although recognised as highly vulnerable, are frequently neglected in research on development and CCA.

This study can potentially inform local and regional policy as it pinpoints possible areas of intervention where strategic activities could support both short-term coping strategies and long-term CCA to address climate change vulnerabilities.

The next section critically reviews the literature on climate change impacts in SIDS, focusing on extreme events and their impacts on livelihoods, including investigating existing knowledge on coping strategies adopted by coastal communities of SIDS. Section three describes the research methods and section four presents the results. Section five contextualises these results, highlighting knowledge gaps and likely barriers to the uptake of effective adaptation measures. Section six discusses the implications for policy and notes areas for further research.

\section{$2 \quad$ Background}

This chapter builds on the growing body of literature that explores how the destabilising climate is affecting coastal communities of SIDS (Kelman, 2018; Nurse et al., 2014), and the coping strategies being adopted by communities in reaction to those impacts.

Coping strategies are generally considered to be impromptu responses, often drawing on existing capital assets, such as livestock or savings, to absorb the impacts of sudden shocks (Ellis, 1998). These short-term coping strategies can be looked at in isolation as simple responses to the hazard (drought, flood, etc.), or by also considering the long-term impacts of climate change (Agrawal, 2008). A recent trend is to link the two concepts of coping strategies and climate change adaptation with an understanding that there is a strong connection between how shortterm coping strategies draw on existing assets and the capacity to ensure a more long-term adaptation to climate change (Berman, Quinn, \& Paavola, 2014). By way of an example, selling livestock or machinery as a strategy employed by households to cope with the immediate impacts of droughts can be juxtaposed to another strategy that instead reduces family expenses or shifts to different food types for a short period, while switching to more drought resistant crops, in order to respond to the threat of prolonged droughts (Birkmann, 2011). 
Furthermore, in recent years there has been a focus on understanding the 'root causes' of hazard vulnerability, and how the severity of climate change impacts is also the result of 'structural deficits' and 'poor' human developments (Pelling, 2003). Therefore, different social, political, and economic systems may determine the capacity of households to respond in the short term, irrespective of the characteristics of the specific hazards (Berman, Quinn, \& Paavola, 2014), and poverty levels within households also create different responses based on stocks of assets (Carter \& Lybbert, 2012).

Useful lessons for many communities in SIDS come from the isolated Indigenous communities in Canada's Western Arctic, who have used traditional knowledge of the environment and past experiences to adopt coping mechanisms capable of dealing with climate change impacts (Mercer, Dominey-Howes, Kelman, \& Lloyd, 2007). Similarly, coastal cities can benefit from community-based adaptation where there is weak infrastructure and few resources, as communities themselves can offer a diverse set of tools and solutions, such as supporting the mapping and enumeration of informal settlements and providing tailor-made coping strategies to respond to immediate and future risks (Mycoo \& Donovan, 2017). It is increasingly recognised that coastal communities in SIDS tend to be aware of and employ effective strategies to cope with climate change impacts (Aswani \& Lauer, 2014; Magee, Verdon-Kidd, Kiem, \& Royle, 2016) while recognising the challenges of low-income and limited financial resources (Beyerl, Mieg, \& Weber, 2018). It is well understood that the characteristics of poverty, such as low-income and poor infrastructure, can act as barriers to the uptake of effective adaptation measures (Klein et al., 2005; Schipper, 2007), even with the presence of development investments in CCA (Ayers \& Huq, 2009).

Considerable attention has been given to investigating the sustainability of coping strategies by households in the face of shocks (Dercon, 2002a), with greater poverty generally associated with a tendency to erode household assets in an effort to cope, for example by selling farm animals or working tools (Dreze \& Sen, 1991; Hoddinott, 2006). Although the flow of assets, which can be taken as a measure of wealth, cannot be understood only using utilitarian approaches (Ferguson, 1985), reduced assets can compromise the coping capacity of households in the face of shocks. Recent developments in the literature have looked for a synthesis between the two concepts (coping and adaptation), with a general understanding that a sustainable short-term coping capacity can also assist the transition to long-term sustainable CCA (Berman, Quinn, \& Paavola, 2012). In fact, it is very likely that the most successful changes in household behaviours will be those that occur gradually over time, stretching the boundaries of previous extremes and building on earlier sustainable coping experiences; the opposite of asset degradation (Engle, 2011).

The relatively scarce literature that examines coping strategies in the face of climate shocks and stressors in the Pacific finds that households, in Fiji for example, only rarely resort to adopting 'unsustainable' coping strategies, like selling as- 
sets, while the majority tend to adopt more sustainable coping mechanisms, such as shifting to different food types and reducing family expenses (Béné et al., 2016).

While there is an understanding that SIDS are diverse, and that not all are affected equally by climate change due to biogeographic and socio-economic differences (Kelman, 2018), there is growing and consistent evidence that anthropogenic climate change is especially hazardous to SIDS populations (Nurse et al., 2014; Walsh et al., 2016), via (for example) loss of land (Albert et al., 2016) and associated displacement and resettlement (Charan, Kaur, \& Singh, 2017) and loss of assets, including valuable crops, due to extreme events (Lashley \& Warner, 2015). Also, the specific characteristics of SIDS, such as socio-economic activities located mostly on the coast, the fragility of generally small markets, and the relatively high reliance on ocean resources, among other factors, make SIDS inherently more vulnerable than other countries to extreme weather and climatic events (Briguglio, 2010). Furthermore, while the heavy reliance of many SIDS on imported goods might offer some temporary protection when local produce is destroyed, this may also cause a change of diet to one that may be nutritionally poorer (Barnett, 2011).

Many islands, notwithstanding these vulnerabilities, have a long history of responding to environmental stressors, resulting in cultural practices, knowledge, and skills to respond (Nunn \& Mimura, 1997), promoting resilience especially in the face of the slow onset of sea-level rise (Nunn, 2007). However, low income, lack of quality education, and poor infrastructure can act as barriers to the effective uptake of CCA (Lemos et al., 2013; Schipper, 2007), including exacerbating exposure to climate change impacts and pushing households to erode their assets in an effort to cope (Carter, Little, Mogues, \& Negatu, 2007). This can be especially significant for remote island communities, where legacies of colonialism (Barnett, Jon, \& Campbell, 2010), demographic dynamics involving both out-migration and highpopulation density (Roberts \& Ibitoye, 2012), and market failures can combine to seriously undermine current and future livelihoods, as well as challenging CCA under the increased recurrence and intensity of environmental and climatic stressors (Nurse et al., 2014). Furthermore, some of the coping strategies that rely on Indigenous knowledge and that are believed to enhance long-term sustainable adaptation are progressively threatened by modemisation, and the reliance upon Western-led development assistance (Mercer et al., 2007).

While research in SIDS progresses, there remains little research on how these climate change impacts are affecting the livelihoods of coastal communities in SIDS (Nunn \& Kumar, 2018), especially given that much of the literature is focused more on urban areas, and less on rural communities, or on those living on remote islands (Nunn, Aalbersberg, Lata, \& Gwilliam, 2014). Furthermore, there is still uncertainty over the extent to which poverty, coupled with island vulnerabilities, affects the capacity of island communities to cope with climate variability and change. Filling these gaps would help inform policy in designing development interventions that could eventually capture context-specific island features to support CCA. 


\section{Context and methods}

\subsection{Context}

Rabi Island is a small, remote Fiji island with a land area of $66.3 \mathrm{~km}^{2}$ and $46 \mathrm{~km}$ of shoreline, located off the east coast of Fiji's second largest island, Vanua Levu. There are four villages: the administrative centre, Tabwewa in the far north, and Uma, Tabiang, and Buakonikai, as shown by Figure 1.

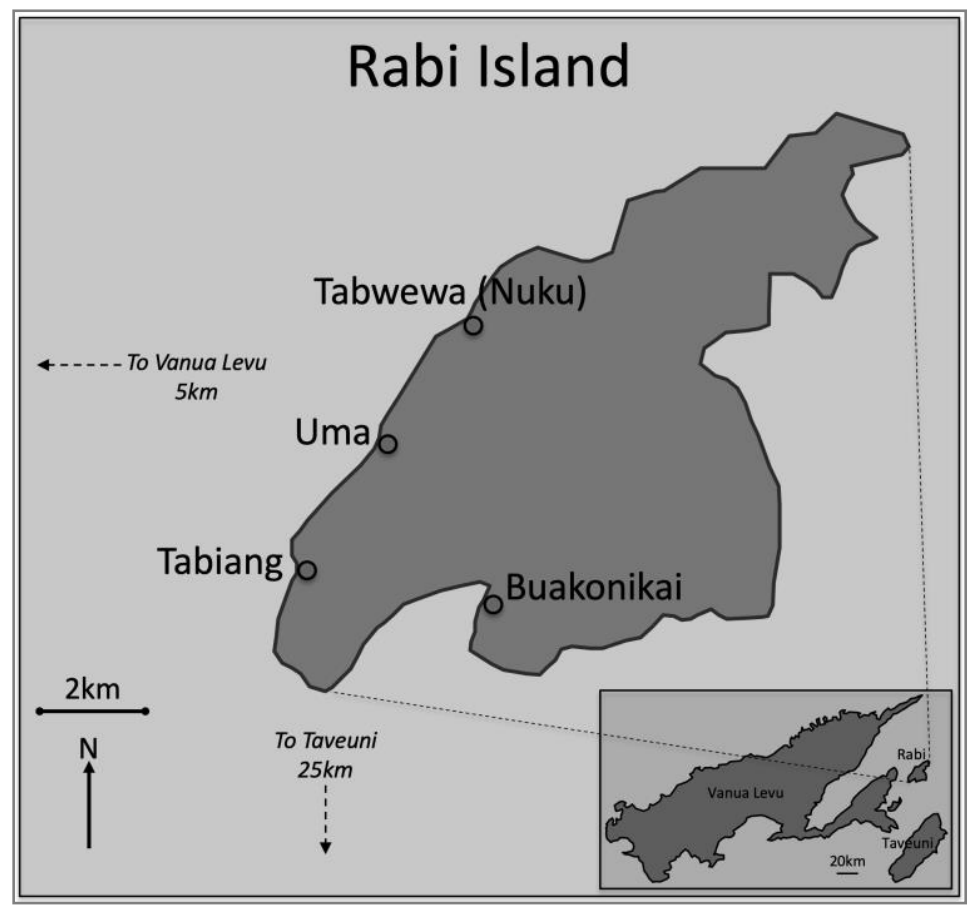

Figure 1: Map showing Rabi Island, off the east coast of Vanua Levu, Fiji.

Rabi is home to around 5,000 Banaba people, descendants of those who were forcibly migrated in 1945 from Banaba Island, Kiribati, as their island was degraded by colonial phosphate mining (Meller, 1997). The islanders retain their Banaba culture and language. The Rabi Council of Leaders and Elders is the municipal statutory body that administers Rabi Island, and has oversight for all operational and development issues of the Banaban Community. The eight-member council has two representatives from each of Rabi's four villages. The council chooses a chairperson, and also selects one of its own members to represent the community in the Kiribati parliament.

There are high levels of poor health, relatively low income, and climate change-related hydrometeorological hazards. Rabi Island was hit, directly or indi- 
rectly, by a series of cyclones that from 2010 have affected the Fijian islands, most recently Cyclone Tomas in 2010, Evan in 2012, Ula in 2015, and the unprecedented Category 5 Cyclone Winston in 2016.

Income is very low and houses are crowded. Communicable diseases such as tuberculosis, as well as diarrhoeal and various mosquito-borne diseases are prevalent, as are non-communicable diseases such as Type 2 diabetes. While there is growing evidence regarding climate change impacts in Fiji at the national level (McIver et al., 2016), little is known about the extent and types of the damages occurring at the local level - or how best to manage them (Bambrick \& Hales, 2013; Nunn et al., 2014) - in specific contexts, and even less is known about more remote communities such as Rabi.

\subsection{Methods}

This chapter presents a case study of the island of Rabi, to focus more specifically on remote communities that are often neglected in research about SIDS, development, and adaptation.

The research employs a mixed methodology. To identify key risks faced by coastal communities, as well as responses to any extreme weather event, and to assess how coping strategies are conducive to long-term sustainable CCA, we conducted Participatory Rural Appraisals (PRAs). The PRAs guided the design of a household survey delivered to a random sample of households $(\mathrm{N}=40)$ living in the coastal areas of the four villages of Rabi and selected with a snowball technique. The survey had the intention of examining the links between poverty levels, measured by households' income, and climate change impacts. Households' income and availability of assets have been used extensively as measures of poverty in the context of developing countries (Grosh \& Glewwe, 1996). We link the variables of interest, households' income, and availability of assets to key climate change impacts, such as flooding, droughts, and cyclones, which are considered appropriate to capture the extent of damage that can affect development (Noy, 2016).

To explore the extent to which coping strategies are conducive to long-term CCA, we adopted the Sustainable Livelihoods Framework which uses categories of livelihood capitals to combine information on climate and development (DalalClayton, \& Sadler, 2014). The SLF, was originally developed by Scoones (1998) to investigate all those causes that make households vulnerable to shocks, and the set of policies and processes that can enhance their resilience following a disaster (Ellis \& Biggs, 2001). We then build on theoretical and applied work advanced by Klein and colleagues (2005), and Schipper (2007), to examine how existing poverty levels are acting as barriers to effective CCA measures. 


\section{Participatory Focus Groups}

The PRAs were conducted using the community-based risks screening tool for adaptation and livelihoods, called CRiSTAL (IISD, IUCN, SEI, \& Intercooperation, 2012), which draws on the SLF approach, by using categories of livelihood capitals to combine information on climate and development (Dalal-Clayton \& Sadler, 2014). The SLF was developed to investigate all those causes that make households vulnerable to risks/shocks, and the set of policies and processes that can enhance their resilience following a disaster (Scoones, 1998; Ellis \& Biggs, 2001). The SLF is an asset-based poverty and vulnerability analytical framework (Carter \& Barrett, 2006). It aims at placing people at the centre of development efforts, and interprets people as deploying assets to reach their objectives in a context of vulnerability (Kemp-Benedict, Bharwani, de la Rosa, Krittasudthacheewa, \& Matin, 2009). Among the advantages of deploying an asset-based livelihoods approach is its capacity to develop effective poverty-reduction interventions (Bebbington, 1999; DFID, 1999).

The CRiSTAL tool was originally introduced as a response to the understanding that sustainable livelihoods projects and ecosystem management could positively contribute to risk reduction and climate change adaptation (IISD \& SEI, 2003), specifically because there was the need for a tool that could systematically identify livelihood resources, or capitals, and the risks/shocks affecting them. These findings would be key to eventually sustaining adaptation strategies that could, in turn, be supported in any development project and used to inform policy (IISD et al., 2012).

PRAs have been used in development, and climate, research for a relatively long time (Chambers, 1994; Labbé et al., 2015), especially to identify contextspecific resources and challenges to overcoming poverty. However, applications of the CRiSTAL tool are more common in continental rural (González, Keller, Tineo, \& Julia, 2011; Stejskal \& Fernandes, 2006), pastoral (Riché \& Hammill, 2009), and forested areas (Robledo, Clot, Hammill, \& Riché, 2012), rather than in island settings. This research therefore extends the application of the CRiSTAL tool to island contexts, including findings related to livelihood resources, risks/shocks, and coping strategies on a remote Pacific island.

The participatory focus groups were conducted by following theoretical (Chambers, 1994) as well as applied work on PRAs, with a focus on the Pacific region (McNaught, Warrick, \& Cooper, 2014; Mercer, Kelman, Taranis, \& SuchetPearson, 2010; Warrick, Aalbersberg, Dumaru, McNaught, \& Teperman, 2017). When selecting participants for the focus groups, we paid particular attention to maximising diversity within the groups (Chambers, 2008; IISD et al., 2012). Separate focus groups were conducted for men and women, to more effectively capture the opinions and perceptions of each group by minimising any potential biases arising from patterns of gender relations, and to address the division of labour within the community (IISD et al., 2012). This also allowed for a more objective 
investigation of the risks (Aboud, 2011), given, for example, a potential inclination for women in mixed groups to talk about the activities and priorities of their husbands rather than their own, as has been found in other settings (Cornwall, 2003). Although some differences between men and women were found, consistent with consolidated norms in reporting PRAs in an aggregated manner there is no need to undertake a gender analysis (Elasha, Elhassan, Ahmed, \& Zakieldin, 2005; Heath, Parker, \& Weatherhead, 2012) but rather to focus on the community as a whole; any specific gender-related research would require further study. The identification, and prioritisation, of the livelihood resources was guided by literature dealing with coding and grouping themes emerging from data analysis (Ritchie, Lewis, Nicholls, \& Ormston, 2013; Strauss \& Corbin, 1990), and by applied research in developing countries (Hargreaves et al., 2007; Sultana \& Thompson, 2004). For each risk or shock and its correspondent impacts, participants identified their current coping strategies, assessed the extent of sustainability of these practices, and then through group discussion proposed alternative strategies, on the assumption that any necessary resources could potentially be employed.

To avoid the perception that categorising behaviours and patterns by using livelihood capitals is too deterministic, and to recognise that local perceptions and realities are complex and at times difficult to categorise, we conducted participatory methods that allowed local communities to inform the content of those preselected categories. As a result of the importance given to religion and religiously based traditions within the communities, we added a specific category, that of cultural capital, within the SLF. Through the use of visual maps, participants were able to identify key livelihood resources, which were then prioritised by participants, with risks and coping mechanisms identified. The drawing of community maps is considered an effective tool to start off discussions on livelihood resources (Cramb, Purcell, \& Ho, 2004; Sheil et al., 2006), with the additional intention of assisting participants who might have barriers to verbal communication (Hart, 1997). The process for selection and prioritisation of livelihood resources was consistent with previous studies of key livelihood resources in developing countries (Neef et al., 2018; Sheuya, 2009), confirming the importance of both tangible and non-tangible capitals (Devereux et al., 2013; Tacoli, 1999).

The two PRAs were conducted during the month of June 2015, and involved coastal communities from two of the four island villages, Uma and Buakonikai. A total of nine participants attended the men's focus group, with age ranging from 19 to 54 (mean age at 34). Seven participants were farmers, one of whom was also an occasional fisherman, while two were religious pastors. A total of seven participants attended the women's focus group, with age ranging from 24 to 60 (mean age at 39). All seven participants declared themselves to be farmers, with one occasionally fishing with her husband.

The focus groups were undertaken with the assistance of a skilled facilitator (Kitzinger \& Barbour, 1999), particularly important in terms of language and cultural specifics in the Pacific setting (Laverack \& Brown, 2003). Attention was given 
to the monitoring of proceedings so as to avoid individual participants 'dominating' the discussion (Laws, Harper, Jones, \& Marcus, 2013).

\section{Surveys}

Surveys were conducted to quantify the relation between extreme events and income. The aim of this part of the study was to assess whether there is an association between poverty levels and relevant climate change hazards, specifically to investigate to what extent lower-income households perceive impacts from extreme events. This part of the research builds on the conceptual framework presented in the previous section, developed by Klein and colleagues (2005) and Schipper (2007), to examine how existing poverty levels are acting as barriers to effective CCA measures. While it is understood that such metrics might have some flaws, especially in areas like the Pacific where measuring wealth from deterministic approaches can run the risk of not capturing cultural and place-based specifics, results from such analysis have the benefits of comparing outcomes from similar research and can lay the groundwork for identifying more appropriate measuring techniques in future research. Furthermore, this specific quantitative investigation complements well the participatory focus groups, by assessing whether, even in the presence of sustainable coping practices following extreme events, financial poverty delays the transition from coping to long-term CCA. This is a preliminary step towards a more sophisticated study using various specialised methodologies, such as community intervention trials, and regression analysis, in order to ascertain causality, which could not be undertaken within the timeframe of this specific research, and given the small sample available. The statistical analysis was performed with the statistical software STATA 13.

The preparation of the survey instrument was also guided by similar studies in developing countries (Crona, Wutich, Brewis, \& Gartin, 2013; Grosh \& Glewwe, 1996), and by relevant research on poverty and climate change (Brown, Daigneault, \& Gawith, 2017), including specific lessons from Fiji (Dumaru, 2010). The survey included questions on household characteristics, public health, including access to and use of sanitation facilities, water and management of environmental resources, prevalence of certain health outcomes, employment, assets, and attitudes and perceptions of environmental changes. The questions included in the final survey were informed by the results of the participatory groups, following the broad categories of capital as identified by the community. The questions in the surveys also attempted to capture data comparable with key national or regional statistics wherever available, such as national censuses of Fiji, and World Bank and World Health Organization Regional and National surveys. ${ }^{1}$

To improve accuracy of response and avoid misinterpretation, multiple-choice responses for frequency ranges were used wherever possible, scales were kept simi-

\footnotetext{
${ }^{1}$ Full survey can be made available upon request.
} 
lar, and time periods were clearly specified (Tourangeau, Rips, \& Rasinski, 2000). The surveys were translated into the most widely understood local languages, Gilbertese and English, and piloted $(\mathrm{n}=10) .{ }^{2}$ We acknowledge that there exists a body of social science research that suggests that closed-ended surveys, where participants are not involved in the creation of the questions or answers, might perpetuate biases and only scratch the surface of issues (Budd, Sigelman, \& Sigelman, 1981), particularly in complex cultural settings like Fiji (Léopold, Cakacaka, Meo, Sikolia, \& Lecchini, 2009). However, we believe that the use of mixed methods in this research where focus group discussions informed the survey questions mitigated the risks of perpetuating such possible biases.

The survey data suffers from some limitations, mostly due to the small sample size $(\mathrm{N}=40)$, and the constraints faced when applying snowballing sampling techniques, such as finding respondents and starting the referral chains, verifying the eligibility of potential respondents, pacing, and monitoring referral chains and data quality (Biernacki \& Waldorf, 1981). There was no formal map or list of households on Rabi Island and so reliable random sampling techniques were less available.

\section{$4 \quad$ Results}

Both the men's and women's focus groups started their discussions by plotting the boundaries of their community, supported by the facilitators, as shown in Figure 2 and Figure 3 below. The use of visual maps helped participants to clearly pinpoint the key resources available, and important, to them, as well as detecting the exact space in the community where risks are occurring and resources are adversely impacted.

2 These 10 pilot household surveys do not form part of the other 40 surveys considered for the analysis. 


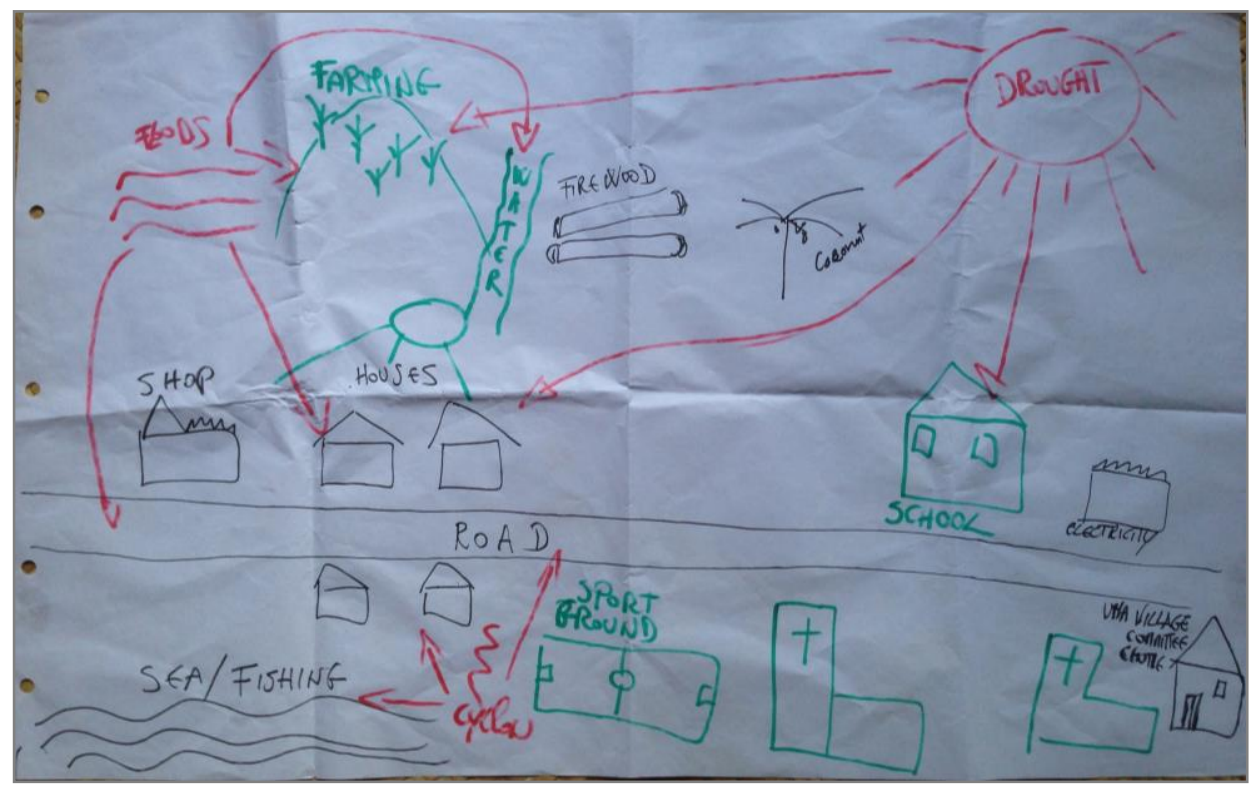

Figure 2: Visual resource map of the men's focus group

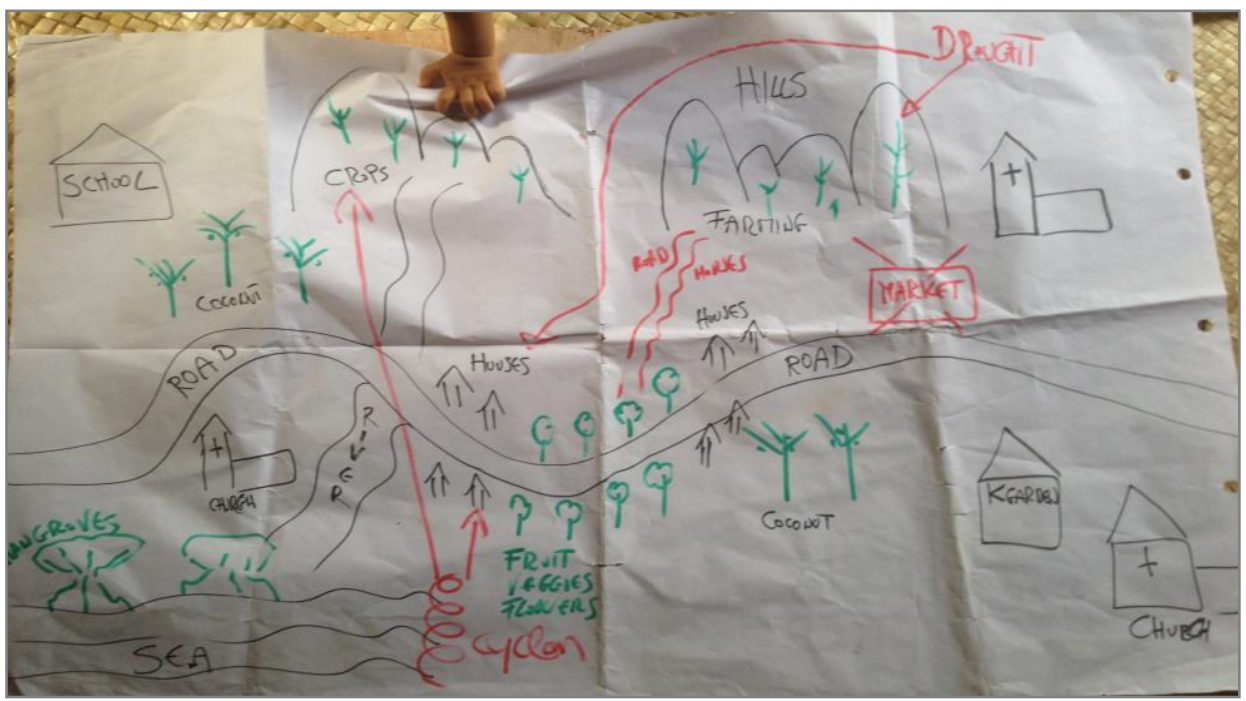

Figure 3: Visual resource map of the women's focus group 


\subsection{Livelihood resources}

Participants identified key livelihood resources according to the categories of the Sustainable Livelihoods Framework, as discussed in the methods section above, and shown in Table 1 below.

Table 1: Identification by men's and women's focus groups of key livelihood resources in Rabi

\begin{tabular}{cl}
\hline Livelihood resource categories & Livelihood resources \\
\hline Human & Education \\
\hline \multirow{2}{*}{ Social } & Networks \\
& Reciprocity and exchange \\
\hline \multirow{3}{*}{ Natural } & Water \\
& Sea \\
& Flowers/trees/firewood \\
& Soil \\
\hline \multirow{2}{*}{ Physical } & Roads \\
& Electricity \\
& Water infrastructure \\
& Schools \\
\hline Financial & Regular inflow of money/income \\
\hline Political & Functioning of the institutions \\
\hline \multirow{2}{*}{ Cultural } & Religion \\
& Sport \\
\hline
\end{tabular}

The discussion on livelihood resources focused especially on natural, physical, social, and human capitals. Water, and ecosystem services more generally, were central, while electricity, social support and reciprocity among community members, and health were listed as priority livelihood resources by participants.

Both the men's and women's groups reported that the water supply system is very poor, running for only two hours in the morning and two hours again in the evening. During the dry season (May to August/September) water availability is especially limited, and participants expressed their concern over what they perceived as a lengthening dry season, when compared to past years, having increasingly frequent detrimental effects on water availability. The main water source was defined as a 'creek', rather than a river, as it only flows with rain. In the wet season (October to April) there is no water shortage, but the colour of the water changes to darker brown given the presence of soil in the water. Not all households filter their water and the filtering that is done is rudimentary, through scraps of fabric tied to the outlet.

All participants recognised the importance of ecosystem services such as flowers, fruit trees, and plants, which provide food for daily consumption and for stor- 
age. The majority of participants were farmers, growing crops such as yaqona (kava), ${ }^{3}$ cassava (tapioca), dalo (taro), and yams. The only products that are sold to local markets are kava and coconut, notwithstanding the availability of other agricultural products that could be sold, but that do not seem to be reaching markets.

Electricity generation is provided by one gallon of diesel per house per month, which translates into two hours of electricity power per day. Participants recognised that their villages are rather small when compared to more populous settlements on other larger islands, or urban areas, and that they have fewer financial resources to generate electricity for longer periods. Households usually buy the diesel to fund 'local electricity committees', which are in charge of the production of electricity through generators. Participants widely agreed that two hours of electricity per day was not enough to satisfy basic livelihood needs, but also stated that it was what they could afford for the time being. All participants agreed that they would be willing to convert to solar but the initial investment was too high. The cost of monthly production of electricity borne by households is approximately 20 Fijian dollars. ${ }^{4} \mathrm{~A}$ solar alternative, following the installation of photovoltaic panels, would be to pay the Fijian government 18 Fijian dollars per month for an unlimited amount of use time. Participants believed the price to be unfair, given that there are no 'refuelling' costs to be sustained and maintenance expenses for solar are lower than those for generators. In order to increase the adoption of solar energy, the government could consider supporting the initial monetary investment, especially in isolated and more remote communities, such as Rabi, and explore gathering returns only through small monthly fees.

Participants mentioned both networking and reciprocity as key resources, confirming the role played by social capital among community members, especially in the face of stressful events, or generally when families are in need. However, participants agreed that there might be constraints in accessing social capital when stressful events affect everyone, such as when cyclones strike, as opposed to when only individuals or individual households are affected, in which instances the support network is more available and accessible.

In terms of health, participants mentioned the importance of improved provision of health services, with some communities being far away from the existing health centres. In case of emergencies they have no means of transport to the hospital, and they risk 'dying in their own villages'.

\footnotetext{
${ }^{3}$ Kava is a soporific drink, traditionally consumed both socially and during ceremonies in Fiji (and other western Pacific Island groups), made from the roots of native pepper plants (most commonly, Piper methysticum).

${ }^{4}$ At the time of writing, US $\$ 1=\mathrm{FJ} \$ 1.83$
} 


\subsection{Risks/shocks}

Following the identification of livelihood resources, the focus groups identified and discussed key risks and shocks, their direct and indirect impacts, current coping strategies for dealing with those risk and shocks, as well as any alternative responses that could be put into place, assuming the availability of resources. Table 2 below shows the aggregated results of both the men's and the women's focus groups.

Table 2: Aggregated results for risks, shocks, and coping strategies for focus groups

\begin{tabular}{|c|c|c|c|}
\hline $\begin{array}{l}\text { Risks/ } \\
\text { Shocks }\end{array}$ & $\begin{array}{l}\text { Direct/Indirect } \\
\text { impacts }\end{array}$ & Current responses & Alternative responses \\
\hline \multirow{6}{*}{ Droughts } & Drinking water & Increase storage $(=)$ & Proper water management \\
\hline & \multirow{4}{*}{$\begin{array}{l}\text { Soil fertility/ } \\
\text { Income loss }\end{array}$} & \multirow{2}{*}{$\begin{array}{l}\text { Reduce food con- } \\
\text { sumption/Shift } \\
\text { other food }(>)\end{array}$} & $\begin{array}{l}\text { Market to sell crops not } \\
\text { affected by drought }\end{array}$ \\
\hline & & & Change cropping behavior \\
\hline & & $\begin{array}{l}\text { Keep weeds to main- } \\
\text { tain moisture }(>)\end{array}$ & 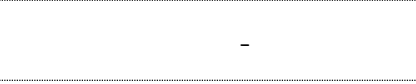 \\
\hline & & Let plants die $(<)$ & $\begin{array}{l}\text { Seek advice from agricultural } \\
\text { services }\end{array}$ \\
\hline & School attendance & $\begin{array}{l}\text { Report and wait for } \\
\text { flow to be restored } \\
(=)\end{array}$ & $\begin{array}{l}\text { Community getting together } \\
\text { to fix problems }\end{array}$ \\
\hline \multirow{3}{*}{ Floods } & $\begin{array}{l}\text { Infrastructural } \\
\text { damage to roads }\end{array}$ & Stay at home $(<)$ & Create diverting channels \\
\hline & $\begin{array}{l}\text { Infrastructural } \\
\text { damage to water } \\
\text { pipes }\end{array}$ & Increase storage $(=)$ & Proper water management \\
\hline & Schools close & Kids at home $(<)$ & Proper building management \\
\hline \multirow{4}{*}{ Cyclones } & Damage to house & $\begin{array}{l}\text { Look for smaller } \\
\text { houses to get tempo- } \\
\text { rary shelter }(=)\end{array}$ & Build with stronger material \\
\hline & \multirow{3}{*}{ Damage to crops } & $\begin{array}{l}\text { Replanting after event } \\
(>)\end{array}$ & Change cropping behavior \\
\hline & & Shift food $(>)$ & Not identified \\
\hline & & Wait for aid $(<)$ & Not identified \\
\hline
\end{tabular}

Note: the symbol ' $>$ ' denotes sustainable coping strategy; ' $<$ ' denotes unsustainable coping strategy; and ' $=$ ' denotes neither sustainable nor unsustainable coping strategy.

\section{Droughts}

Participants from both focus groups mentioned that from 1997 onwards there has been a severe drought every year, and that in each of the past five consecutive years there has been an unusually long dry season, which lasted for more than eight months. They also mentioned that the quality of the soil has been profoundly af- 
fected by unusually prolonged droughts, negatively impacting farming practices and yields. During the previous farming season, one specific farmer declared he had more than 700 plants die from lack of sufficient water. There are currently no means of irrigation in the fields. When droughts happen, young crops die, and if the drought is especially long, even well-established plants are affected. During droughts, coconuts stay on the trees rather than fall to the ground, making it more difficult to collect them. Kava gives a smaller yield during droughts, hence income from this important cash crop is also reduced. The schools close down when there is no water, with these closures continuing for up to a whole week, potentially affecting women's work and activities given their traditional role as caretakers, and overall leading to the loss of education that is perceived as important by the community.

During the dry season the density of pest insects increases, damaging green leafy edible plants. Food security on the island is tenuous. With the lengthening dry season and frequent prolonged droughts, households shift to different food types, when available and when income is sufficient to purchase them, or resort to reduced food intakes.

Both focus groups independently raised the point that a recent 'massive' logging operation by an international company cut many trees in the central part of the island and 'intensified' the droughts, as well as damaging the nearby fields.

\section{Floods}

In the wet season floods are seldom, but very damaging when they occur. Those households close to the rivers/creeks are highly affected. Floods damage houses, soil, farming, road transportation, and employment. Floods can contaminate water and cut supply as they burst pipes. During heavy floods the school is closed as water supply and sanitation cannot be guaranteed.

Crops are planted in the wet season (October to May), before the dry season arrives, but flooding can be a risk, washing away the seeds, or uprooting small plants.

\section{Cyclones}

The cyclone season is from November to April. There was a general agreement among participants that particularly heavy cyclones have become more likely to hit Rabi Island in recent years. Participants especially remember the damages inflicted by the 2003 Cyclone Amy, and the 2010 Cyclone Tomas. (Data collection took place shortly before the record-breaking Category 5 Cyclone Winston in 2016.)

The damage wreaked by cyclones can be extreme, destroying houses and crops. Crops most affected are those that grow above the soil, such as banana and papaya. Crops such as dalo, cassava, and yams do better, since they grow below the soil. As well as cyclones, other extreme weather events were cited as happening 
more frequently, once or twice every season, especially wind storms. Participants reported that stronger winds started to happen from the 1980s, making it more difficult to plan farming and fishing activities.

Participants mentioned the lack of larger, functional markets and somewhere to sell excess yields as a chronic problem that prevents many community members from increasing their income, and from recovering faster from shocks arising from climate change. Participants mentioned that they would be happy to sell more agricultural products, but that there is simply no market where they can do so, either locally or on other islands (transport to the nearest islands is by small boat over distances of $5 \mathrm{~km}$ to $25 \mathrm{~km}$, which can be treacherous in poor weather, and then several hours by road to the nearest town). Another problem that participants highlighted was the lack of roads on Rabi Island itself to and from the fields, as well as lack of vehicles, which also limits how much produce can be transported, and negatively affects its quality and price.

The absence of a market also places limits on the choice of items available for households to purchase, including tools that could be used to improve their productivity, and food items, leading to poorer nutritional intake from a limited range of highly processed foods that are brought to the island in bulk and infrequently.

\subsection{Coping strategies}

For each risk and its correspondent impacts, participants identified their current coping strategies, assessed the extent of sustainability of these practices, and then through discussion proposed alternative strategies on the assumption that any necessary resources could be employed.

\section{Coping with droughts}

To cope with the lack of water during the dry season participants reported that they collect more water using bigger buckets, therefore trying to increase storage; however, this comes at an extra cost given the need to acquire, or borrow, further water containers. The alternative, more sustainable strategy proposed by participants was to have a bigger reservoir, or to be connected to a well. They also recognised that a better long-term solution would be to have a more efficient water management system (i.e. not just more water, but also distributing and using it more efficiently), while noting that because of a lack of financial resources on the island this is unrealistic in the near future. By way of confirming the lack of funding available to the council, participants referred to the fact that the Rabi council recently had to reduce by half the number of employees, from 70 to 35 .

To cope with droughts in farming, many participants noted the usual practice of not clearing the grass near young plants, increasing the soil moisture to protect the plants from dying, even if it produces a lower yield overall as the grass com- 
petes for nutrients. Many also mentioned early harvesting as a way to ensure some, albeit again limited, produce before extended drought kills the plants.

During the dry season participants reported having a lower income, causing them to change what they eat to more readily available or less expensive items, and to even eat less overall.

\section{Coping with floods}

When floods hit the island's infrastructure, especially roads, participants noted they would be unable to go to work, although they said their income would be rarely impacted, with the exception of floods lasting for more than two or three days, in which case, especially for farmers and small traders, income can be affected. This is probably why to avoid floods constraining their everyday activities, participants described how channels alongside the roads should be dug and other infrastructural work should be undertaken by the local council, and that they would be willing to assist such activities by investing their own time and energy into these sorts of improvements.

\section{Coping with cyclones}

Following a severe cyclone, participants described how overseas aid, usually through the Red Cross, arrives on Rabi as well as supplies food, clothes, and tools. During cyclones, the farmers go to the fields to check on crops or stay in their houses, or, if the cyclone is particularly severe, seek shelter in the church or other strong buildings.

Participants also reported that following damage to houses from a cyclone they will sometimes build a small temporary hut where they can sleep, then build a small house as an interim solution, waiting to build, eventually, a bigger house when further resources are collected, or external assistance is provided. Among the food crops less likely to be damaged by cyclones are the roots of a plant called 'papai', as well as yam, cassava, and dalo; otherwise, the vast majority of the other crops need to be replaced by farmers following cyclones. Interestingly, notwithstanding the importance of kava, which besides having cultural and recreational values is also used as a cash crop, participants did not mention any loss of this crop when hit by cyclones, contrary to findings in other Pacific Islands (Le Dé, Rey, Leone, \& Gilbert, 2018).

Participants clearly understood that the lack of functional markets on the island directly affects their capacity to produce an income, and limits their investment in increasing their own standards of living. They believed that the Rabi council should help establish a market for them to be able to sell their produce, as well as lobby the Fiji government to provide suitable transport and infrastructure to directly link production to markets on neighbouring islands. Participants also stat- 
ed that they would be willing to plant more crops and to diversify their production in order to increase their market share in nearby markets.

\subsection{Key community characteristics and statistical analysis}

The socio-demographic data collected in the survey is fairly representative of key characteristics in the national and provincial population (specifically that of the Cakaudrove Province) (Table 3), including household size, marital status, religious affiliation, literacy levels, and health behaviours, such as tobacco use. However, means for household income are significantly lower and unemployment rates higher for households residing in the communities when compared to national and provincial means. This is not unexpected, as more remote islands tend to have higher poverty levels (Fiji Bureau of Statistics, 2017).

Table 3: Community vs. provincial/national characteristics

\begin{tabular}{lcc}
\hline Key variables & $\begin{array}{c}\text { Household } \\
\text { means }\end{array}$ & $\begin{array}{c}\text { Provincial/national } \\
\text { means }\end{array}$ \\
\hline Number of people per household & 6.6 & $5.2^{1}$ \\
Married & $38 \%$ & $39 \% 0^{1}$ \\
Christians & $87.5 \%$ & $85 \% 0^{1}$ \\
Literacy rate & $92 \%$ & $98.7 \%{ }^{1}$ \\
Tobacco use & $30 \%$ & $31 \% 0^{3}$ \\
Household income (USD per day) & 1.33 & $13.52^{2}$ \\
Unemployment rate & $27 \%$ & $8.6 \%{ }^{1}$ \\
\hline Notes: ${ }^{1}$ Fijian Bureau of Statistics, $2017 ;{ }^{2}$ World Bank Indicators, $2017 ;{ }^{3} \mathrm{WHO}, 2016$.
\end{tabular}

We examined whether, and to what extent, poverty levels measured by households income, are interacting with climate change impacts in coastal island communities. Here we run pairwise correlations ${ }^{5}$ between households' income and level of agreement on a number of proxies for climate change. These proxies were informed by discussion in the participatory focus groups and include, namely:

- Flooding has been increasing in recent years.

- Drought has been increasing in recent years.

- Cyclones are happening more often in recent years.

- It is becoming more difficult to catch fish in recent years. ${ }^{6}$

The correlation coefficients ${ }^{7}$ reported in Table 4 send a clear message; that there is a negative correlation between households' income and level of agreement

\footnotetext{
5 Pairwise correlation was preferred to regression as a technique given the relatively small sample. Furthermore, the study is an initial exploration with no intention, for the time being, to infer any causation or construct any model.

${ }^{6}$ These four variables are measured by a Likert scale ranging between 1 and 5, with 1 being 'strongly disagree' and 5 representing 'strongly agree'.

${ }^{7}$ Correlation matrix available upon request.
} 
with the three variables used to measure climate change impacts. More specifically, the lower the income levels, the higher the perception that floods, droughts, and cyclones are happening more frequently in recent years. Interestingly, if we repeat the exercise by substituting income for variables measuring assets, such as number of chickens owned, or measures of deprivation, such as going without electricity or food, the same statistically significant association holds. ${ }^{8}$ On the other hand, results from the variable measuring fish catches, does not seem to be correlated with any of the variables measuring poverty levels.

Table 4: Pairwise correlation between key climate change impacts and household income

\begin{tabular}{lcc}
\hline Variables & $\begin{array}{c}\text { Correlation } \\
\text { coefficient }\end{array}$ & $\begin{array}{c}\text { Households } \\
\text { sampled }\end{array}$ \\
\hline Flooding has been increasing in the recent years & $-0.276^{*}$ & 40 \\
Drought has been increasing in recent years & $-0.301^{* *}$ & 40 \\
Cyclones are happening more often in recent years & $-0.266^{*}$ & 40 \\
It is becoming more difficult to catch fish in recent years & 0.120 & 40 \\
\hline
\end{tabular}

Note: * statistically significant at the $95 \%$ level; $* *$ statistically significant at the $99 \%$ level.

\section{Discussion}

We found that the majority of the shocks identified by coastal communities on Rabi Island are related to climate, adding weight to prior understanding of coastal SIDS communities (Nunn et al., 2014), and providing a new level of important detail, especially on the negative impacts among local fishers and farmers (Cinner et al., 2012). Of particular importance is the confirmation that droughts and floods represent a serious threat to local livelihoods, as demonstrated by previous studies in the Pacific, where household crops and local businesses are highly monetarily vulnerable to floods, especially areas with inadequate infrastructure (Brown et al., 2017). Rabi Island as a case study confirms existing understanding in relation to communities living on remote islands, and perceptions of the changing frequency and intensity of such events in recent times.

Interestingly, community members mentioned logging operations on the island as a possible factor that intensified the negative effects of droughts, reducing the capacity of the nearby soil to keep moisture and unduly exposing plantations, as well as creating erosion and loss of soil, including a reduced transpiration from the (now diminished) forests leading to less rainfall. While such effects of deforestation are well established (Myers, 1988), including in Fiji (Stephens, Lowry, \& Ram, 2018), there appears to be little previous evidence from remote islands. This could

\footnotetext{
8 These further results are not reported in this paper but are available upon request. The variable of income, as well as the additional variables used to measure poverty such as food deprivation and number of chickens owned, are all normally distributed.
} 
be a valuable focus of future research, including on the broader and long-term costs of such economic operations, such as the impacts on local farming activities, any local benefits of payments received by the logging company, and the potential indirect damage that deforestation causes to infrastructure, such as through flooding, and even, as suggested here by participants, an impact on island rainfall patterns. Such economic choices, occurring even within cash poor small island economies (Chand Satish, 2003; Feeny, 2016), could potentially erode existing assets, and be costlier and more unsustainable in the long term (Myers, 1988).

This study finds that participants tend to adopt sustainable short-term coping strategies when hit by shocks. Shifting to lower food consumption, or to other types of food, in the face of decreased income or availability of farmed products, has been consistently considered an appropriate way of coping with such shocks (Davies, 1993; Dercon, 2002b; Drysdale, Moshabela, \& Bob, 2019). This is also the case for farming practices that keep weeds around the farmed crops, keeping crop plants alive but with decreased yield. This sustainable coping practice is also well known elsewhere (McGregor, Fink, \& Dawson, 2016). The existence of sustainable short-term coping strategies can nourish fertile ground for long-term CCA, especially when institutions, including the family and supportive cultural institutions, can support this transition (Berman et al., 2012). Further important elements for an effective transition from short-term coping strategies to long-term CCA is the integration of traditional knowledge and cultural practices into responses to shocks (Eriksen et al., 2011), which feature in the coping strategies adopted by communities on Rabi Island. Our findings support those of studies conducted elsewhere in Fiji (Béné et al., 2016), but with evidence from isolated rural communities.

Participants appeared to be aware of long-term solutions that could address the direct and indirect impacts of climate shocks hitting their communities. This is in line with a large body of literature showing communities that are highly attuned to long-term changes, and that understand and appreciate longer-term potential solutions using local culture and knowledge (Barnett \& Campbell, 2010; Kelman, 2010; Lata \& Nunn, 2012; Mortreux \& Barnett, 2009). This includes the need to build a better water management system, comprising drip irrigation in the fields to cope with extended periods of drought and more robust pipes and better drainage to cope with floods. Furthermore, there is a clear understanding that schools and other community buildings, as well as private homes, should be built to improved standards that better withstand the impact of cyclones and floods, thus decreasing the long-term costs associated with disrupted education and recurrent reconstruction.

A further issue that the communities seem to face is the lack of suitable markets to sell their products. Farmers and fishers reported that, notwithstanding ongoing surplus in the production, the local market is not sufficient to absorb even their usual harvest and this keeps prices too low. There is also no organised form of transport that could allow participation in other markets on nearby islands. 
Although many participants were aware of the importance of adopting sustainable coping strategies, inherent vulnerabilities and existing poverty levels do act as barriers to the adoption of long-term adaptation measures, threatening current coping strategies and future livelihoods.

We found that income is associated with the perceived frequency of climate change impacts. There is a negative correlation between income - or assets - and frequency of climate change-related events. While measuring such impacts with proxy variables that capture perceptions rather than using some objective measure of events (e.g. an analysis of rainfall patterns over several decades using rainfall observations) might suffer from some limitations (Bird, 2009), the observed data and climate projections in the Pacific Region (Brown et al., 2017; Nurse et al., 2014), as well as the results of the qualitative focus groups conducted here, support these findings.

\section{Conclusion}

This study's objective was to investigate how coastal communities on the island of Rabi are affected by climate change, and in particular to better understand the coping strategies that are employed in response to hazards associated with climate variability and change. We also explored whether these responses are conducive to long-term and more sustainable climate change adaptation. In addition, we investigated the extent to which characteristics of poverty (low income and few assets) interact with climate impacts, potentially affecting the successful uptake of both short-term coping strategies and long-term climate change adaptation measures.

Our findings show that the majority of the shocks faced by communities on Rabi are related to climate, contributing to a growing body of literature showing how communities are highly attuned to variability and even long-term changes, and understand and appreciate potential longer-term strategies using local culture and knowledge, especially in coastal communities of SIDS (McCubbin et al., 2015; Nunn et al., 2014), on the negative impacts on local fishers (Cinner et al., 2012) and farmers (Harmer \& Rahman, 2014; Iese, Maeke, Holland, Wairiu, \& Naidu, 2017). The chapter adds to the evidence on existing awareness in local communities about the adoption of sustainable coping strategies in the face of climatic shocks (Raymond et al., 2010), where empirical research has been scarce (Costella \& Ivaschenko, 2015), including on remote islands in the Pacific. Our findings may be applicable to other islands which are similarly isolated, low-income, and reliant on subsistence agriculture and fisheries exposed to climate risks.

Our findings also suggest that sustainable short-term coping strategies, likely to lead to long-term CCA, are threatened by already apparent impacts of climate change, such as prolonged dry seasons and frequent drought, and that this may be especially the case for low-income households. Results from the surveys show that the perception of the frequency of floods, droughts, and cyclones and associated 
risks was stronger among low-income households. Remoteness and the higher costs of production and access to markets may act as insurmountable barriers to the adoption of long-term adaptation measures among low-income households. This threatens contemporary livelihoods and undermines potential future gains in standards of living and in health and wellbeing. Such results seem to support the understanding that the removal of 'development barriers', such as poverty and lack of functioning infrastructure and institutions (Schipper, 2007), could be tackled first, especially in the presence of limited resources to invest, in order to create fertile ground for sustainable and long-lasting CCA (Eakin, Lemos, \& Nelson, 2014).

These findings can potentially inform more effective strategies and adaptation policy for Rabi Island, especially by providing detailed information on the specific climate shocks and likely barriers to adaptation, and highlight the areas where further actions are needed to promote transition from short-term coping strategies to longer-term climate change adaptation.

\section{Bibliography}

Aboud, G. (2011). Gender and climate change - supporting resource collection. Brighton, UK: Institute of Development Studies.

Adger, W. N., Huq, S., Brown, K., Conway, D., \& Hulme, M. (2003). Adaptation to climate change in the developing world. Progress in Development Studies, 3(3), 179-195.

Adger, W. N., Brown, K., Nelson, D. R., Berkes, F., Eakin, H., Folke, C., . . O'Brien, K. (2011). Resilience implications of policy responses to climate change. WIREs Climate Change, 2(5), 757-766.

Agrawal, A. (2008). The role of local institutions in adaptation to climate change. Washington, DC: World Bank.

Albert, S., Leon, J. X., Grinham, A. R., Church, J. A., Gibbes, B. R., \& Woodroffe, C. D. (2016). Interactions between sea-level rise and wave exposure on reef island dynamics in the Solomon Islands. Environmental Research Letters, 11(5), 054011.

Aswani, S., \& Lauer, M. (2014). Indigenous people's detection of rapid ecological change. Conservation Biology, 28(3), 820-828.

Ayers, J. M., \& Huq, S. (2009). Supporting adaptation to climate change: What role for official development assistance? Development Policy Review, 27(6), 675-692.

Bambrick, H., \& Hales, S. (2013). Climate adaptation strategy for health and action plan. Samoa: Government of Samoa and United Nations Development Programme.

Barnett, J., \& Campbell, J. (2010). Climate change and small island states: Power, knowledge and the South Pacific. London: Earthscan Publications.

Barnett, J., \& O’Neill, S. (2010). Maladaptation. Global Environmental Change, 20(2), 211-213. 
Bebbington, A. (1999). Capitals and capabilities: A framework for analyzing peasant viability, rural livelihoods and poverty. World Development, 27(12), 2021-2044.

Béné, C., Al-Hassan, R. M., Amarasinghe, O., Fong, P., Ocran, J., Onumah, E., ... Mills, D. J. (2016). Is resilience socially constructed? Empirical evidence from Fiji, Ghana, Sri Lanka, and Vietnam. Global Environmental Change, 38, 153-170.

Berman, R., Quinn, C., \& Paavola, J. (2012). The role of institutions in the transformation of coping capacity to sustainable adaptive capacity. Environmental Development, 2, 86-100.

Berman, R. J., Quinn, C. H., \& Paavola, J. (2014). Identifying drivers of household coping strategies to multiple climatic hazards in western Uganda: Implications for adapting to future climate change. Climate and Development, 7(1), 71-84.

Beyerl, K., Mieg, H. A., \& Weber, E. (2018). Comparing perceived effects of climate-related environmental change and adaptation strategies for the Pacific small island states of Tuvalu, Samoa, and Tonga. Island Studies Journal, 13(1).

Biernacki, P., \& Waldorf, D. (1981). Snowball sampling: Problems and techniques of chain referral sampling. Sociological Methods \& Research, 10(2), 141-163.

Bird, D. K. (2009). The use of questionnaires for acquiring information on public perception of natural hazards and risk mitigation-a review of current knowledge and practice. Natural Hazards and Earth System Sciences, 9(4), 1307-1325.

Birkmann, J. (2011). First- and second-order adaptation to natural hazards and extreme events in the context of climate change. Natural Hazards, 58(2), 811-840.

Briguglio, L. (2010). Defining and assessing the risk of being harmed by climate change. International Journal of Climate Change Strategies and Management, 2(1), 23-34.

Brown, K. (2011). Sustainable adaptation: An oxymoron? Climate and Development, 3(1), 21-31.

Brown, P., Daigneault, A., \& Gawith, D. (2017). Climate change and the economic impacts of flooding on Fiji. Climate and Development, 9(6), 493-504.

Budd, E. C., Sigelman, C. K., \& Sigelman, L. (1981). Exploring the outer limits of response bias. Sociological Focus, 14(4), 297-307.

Carter, M. R., \& Barrett, C. B. (2006). The economics of poverty traps and persistent poverty: An asset-based approach. The Journal of Development Studies, 42(2), 178-199.

Carter, M. R., Little, P. D., Mogues, T., \& Negatu, W. (2007). Poverty traps and natural disasters in Ethiopia and Honduras. World Development, 35(5), 835-856.

Carter, M. R., \& Lybbert, T. J. (2012). Consumption versus asset smoothing: Testing the implications of poverty trap theory in Burkina Faso. Journal of Development Economics, 99(2), 255-264. 
Cashman, A., \& Nagdee, M. R. (2017). Impacts of climate change on settlements and infrastructure in the coastal and marine environments of Caribbean Small Island Developing States (SIDS). Science Review, 2017, 155-173.

Chambers, R. (1994). The origins and practice of participatory rural appraisal. World Development, 22(7), 953-969.

Chambers, R. (2008). From PRA to PLA and pluralism: Practice and theory. In P. Reason, \& H. Bradbury (Eds.), The SAGE handbook of action research: Participative inquiry and practice (Second ed., pp. 297-318). London: SAGE.

Chand Satish. (2003). Economic trends in the Pacific Island Countries. Pacific Economic Bulletin, 18(1), 1-15.

Charan, D., Kaur, M., \& Singh, P. (2017). Customary land and climate change induced relocation - a case study of Vunidogoloa village, Vanua Levu, Fiji. In W. Leal Filho (Ed.), Climate change adaptation in Pacific countries (pp. 19-33). Cham: Springer.

Cinner, J. E., McClanahan, T. R., Graham, N. A. J., Daw, T. M., Maina, J., Stead, S. M., . . . Bodin, Ö. (2012). Vulnerability of coastal communities to key impacts of climate change on coral reef fisheries. Global Environmental Change, 22(1), $12-20$.

Cornwall, A. (2003). Whose voices? Whose choices? Reflections on gender and participatory development. World Development, 31(8), 1325-1342.

Costella, C., \& Ivaschenko, O. (2015). Integrating disaster response and climate resilience in social protection programs in the Pacific Island countries. Social Protection and Labour World Bank, 1(1507), 1-68.

Cramb, R. A., Purcell, T., \& Ho, T. (2004). Participatory assessment of rural livelihoods in the central highlands of Vietnam. Agricultural Systems, 81(3), 255-272.

Crona, B., Wutich, A., Brewis, A., \& Gartin, M. (2013). Perceptions of climate change: Linking local and global perceptions through a cultural knowledge approach. Climatic Change, 119(2), 519-531.

Dalal-Clayton, B., \& Sadler, B. (2014). Sustainability appraisal: A sourcebook and reference guide to international experience. London: Routledge.

Davies, S. (1993). Are coping strategies a cop out? IDS Bulletin, 24(4), 60-72.

Dercon, S. (2002a). Income risk, coping strategies, and safety nets. The World Bank Research Observer, 17(2), 141-166.

Deressa, T. T., Hassan, R. M., \& Ringler, C. (2011). Perception of and adaptation to climate change by farmers in the Nile basin of Ethiopia. The Journal of Agricultural Science, 149(01), 23-31.

Devereux, S., Roelen, K., Béné, C., Chopra, D., Leavy, J., \& McGregor, J. A. (2013). Evaluating outside the box: An alternative framework for analysing social protection programmes. IDS Working Papers, 2013(431), 1-26.

DFID. (1999). Sustainable livelihoods guidance sheets. London: UK Department for International Development.

Dreze, J., \& Sen, A. (1991). Hunger and public action (First ed.). Oxford: Oxford University Press. 
Drysdale, R. E., Moshabela, M., \& Bob, U. (2019). Adapting the coping strategies index to measure food insecurity in the rural district of iLembe, South Africa. Food, Culture \& Society, 22(1), 95-110.

Dumaru, P. (2010). Community-based adaptation: Enhancing community adaptive capacity in Druadrua Island, Fiji. WIREs Climate Change, 1(5), 751-763.

Eakin, H. C., Lemos, M. C., \& Nelson, D. R. (2014). Differentiating capacities as a means to sustainable climate change adaptation. Global Environmental Change, 27, $1-8$.

Elasha, B. O., Elhassan, N., Ahmed, H., \& Zakieldin, S. (2005). Sustainable livelibood approach for assessing community resilience to climate change: Case studies from Sudan, ALACC working paper. Sudan: Higher Council for Environment and Natural Resources.

Ellis, F. (1998). Household strategies and rural livelihood diversification. The Journal of Development Studies, 35(1), 1-38.

Ellis, F., \& Biggs, S. (2001). Evolving themes in rural development 1950s-2000s. Development Policy Review, 19(4), 437-448.

Engle, N. L. (2011). Adaptive capacity and its assessment. Global Environmental Change, $21(2), 647-656$.

Eriksen, S., Aldunce, P., Bahinipati, C. S., Martins, R. D., Molefe, J. I., Nhemachena, C., ... Sygna, L. (2011). When not every response to climate change is a good one: Identifying principles for sustainable adaptation. Climate and Development, 3(1), 7-20.

Feeny, S. (2016). Household vulnerability and resilience to economic shocks: Findings from Melanesia. London: Routledge.

Ferguson, J. (1985). The bovine mystique: Power, property and livestock in rural Lesotho. Man, 20(4), 647-674.

Fiji Bureau of Statistics. (2017). Census of population and housing. Suva: Fiji Bureau of Statistics. Retrieved from http://www.statsfiji.gov.fj/statistics/2007-census-ofpopulation-and-housing.

González, M. A., Keller, M., Tineo, E., \& Julia, E. (2011). Proyecto de asesoría técnica en gestión de riesgo climático - reporte final de los talleres CRiSTAL en repuiblica dominicana. London: IISD.

Grosh, M. E., \& Glewwe, P. (1996). Household survey data from developing countries: Progress and prospects. The American Economic Review, 86(2), 15-19.

Hargreaves, J. R., Morison, L. A., Gear, J. S., Makhubele, M. B., Porter, J. D., Busza, J., . . Pronyk, P. M. (2007). "Hearing the voices of the poor": Assigning poverty lines on the basis of local perceptions of poverty. A quantitative analysis of qualitative data from participatory wealth ranking in rural South Africa. World Development, 35(2), 212-229.

Harmer, N., \& Rahman, S. (2014). Climate change response at the farm level: A review of farmers' awareness and adaptation strategies in developing countries. Geography Compass, 8(11), 808-822. 
Hart, R. (1997). Children's participation in sustainable development: The theory and practice of involving young citizens in community, development and environmental care. London: Earthscan.

Heath, T. T., Parker, A. H., \& Weatherhead, E. K. (2012). Testing a rapid climate change adaptation assessment for water and sanitation providers in informal settlements in three cities in Sub-Saharan Africa. Environment and Urbanization, 24(2), 619-637.

Hoddinott, J. (2006). Shocks and their consequences across and within households in rural Zimbabwe. Journal of Development Studies, 2(42), 301-321.

Iese, V., Maeke, J., Holland, E., Wairiu, M., \& Naidu, S. (2017). Farming adaptations to the impacts of climate change and extreme events in Pacific Island countries: Case study of Bellona Atoll, Solomon Islands. Natural resources management: Concepts, methodologies, tools, and applications (pp. 852-875). IGI Global.

IISD \& SEI. (2003). Livelihoods and climate change. Winnipeg, Manitoba Canada: International Institute for Sustainable Development, International Union for Conservation of Nature and Natural Resources and Stockholm Environment Institute.

IISD, IUCN, SEI, \& Intercooperation. (2012). CRiSTAL - community-based risk screening tool adaptation and livelihoods. London: IISD.

Juhola, S., Glaas, E., Linnér, B., \& Neset, T. (2016). Redefining maladaptation. Environmental Science \&o Policy, 55, 135-140.

Kelman, I. (2010). Introduction to climate, disasters and international development. Journal of International Development, 22(2), 208-217.

Kelman, I. (2018). Islandness within climate change narratives of Small Island Developing States (SIDS). Island Studies Joumal, 13(1), 149-166.

Kemp-Benedict, E., Bharwani, S., de la Rosa, E., Krittasudthacheewa, C., \& Matin, N. (2009). Assessing water-related poverty using the Sustainable Livelihoods Framework. Working Paper. Stockholm Institute for Environment.

Kitzinger, J., \& Barbour, R. (1999). Developing focus group research: Politics, theory and practice. London: Sage.

Klein, R. J. T., Schipper, E. L. F., \& Dessai, S. (2005). Integrating mitigation and adaptation into climate and development policy: Three research questions. Environmental Science \& Policy, 8(6), 579-588.

Konseiga, A. (2006). Household migration decisions as survival strategy: The case of Burkina Faso. Journal of African Economies, 16(2), 198-233.

Labbé, J., Dewey, C. E., Weber, L. J., McIntyre, J., Hoekstra, K., \& Klapwyk, C. (2015). Strategic planning through a participatory learning and action framework: A Kenyan study. Development in Practice, 25(2), 277-287.

Lashley, J. (2013). 'Saving for a rainy day': Coping with extreme weather events in Small Island Developing States. Joumal of Eastern Caribbean Studies, 38(3), 29-62.

Lashley, J. G., \& Warner, K. (2015). Evidence of demand for microinsurance for coping and adaptation to weather extremes in the Caribbean. Climatic Change, 133(1), 101-112. 
Lata, S., \& Nunn, P. D. (2012). Misperceptions of climate-change risk as barriers to climate-change adaptation: A case study from the Rewa Delta, Fiji. Climatic Change, 110(1-2), 169-186.

Laws, S., Harper, C., Jones, N., \& Marcus, R. (2013). Research for development: A practical guide. London: Sage.

Le Dé, L., Rey, T., Leone, F., \& Gilbert, D. (2018). Sustainable livelihoods and effectiveness of disaster responses: A case study of Tropical Cyclone Pam in Vanuatu. Natural Hazards, $91(3), 1203-1221$.

Lemos, M. C., Agrawal, A., Eakin, H., Nelson, D. R., Engle, N. L., \& Johns, O. (2013). Building adaptive capacity to climate change in less developed countries. In G. R Asrar \& J.W. Hurrell (Eds.), Climate science for serving society (pp. 437457). Cham: Springer.

Léopold, M., Cakacaka, A., Meo, S., Sikolia, J., \& Lecchini, D. (2009). Evaluation of the effectiveness of three underwater reef fish monitoring methods in Fiji. Biodiversity and Conservation, 18(13), 3367.

Magee, A. D., Verdon-Kidd, D. C., Kiem, A. S., \& Royle, S. A. (2016). Tropical cyclone perceptions, impacts and adaptation in the southwest Pacific: An urban perspective from Fiji, Vanuatu and Tonga. Natural Hazards and Earth System Sciences, 16(5), 1091-1105.

McCubbin, S., Smit, B., \& Pearce, T. (2015). Where does climate fit? Vulnerability to climate change in the context of multiple stressors in Funafuti, Tuvalu. Global Environmental Change, 30, 43-55.

McGregor, A., Fink, A., \& Dawson, B. (2016). Implications of climate change for contributions by agriculture and forestry to Pacific island economies and communities. In M. Taylor, A. McGregor \& B. Dawson (Eds.), Vulnerability of Pacific Island agriculture and forestry to climate change (pp. 447-482). Noumea: Pacific Community.

McIver, L., Kim, R., Woodward, A., Hales, S., Spickett, J., Katscherian, D., . . . Iddings, S. (2016). Health impacts of climate change in Pacific Island Countries: A regional assessment of vulnerabilities and adaptation priorities. Environmental Health Perspectives, 124(11), 1707.

McNaught, R., Warrick, O., \& Cooper, A. (2014). Communicating climate change for adaptation in rural communities: A Pacific study. Regional Environmental Change, 14(4), 1491-1503.

Meller, N. (1997). Ethnic and racial cleavages in Pacific Island constitutions. The Journal of Pacific History, 32(2), 203-208.

Mercer, J., Dominey-Howes, D., Kelman, I., \& Lloyd, K. (2007). The potential for combining Indigenous and Western knowledge in reducing vulnerability to environmental hazards in Small Island Developing States. Environmental Hazards, 7(4), 245-256.

Mercer, J., Kelman, I., Taranis, L., \& Suchet-Pearson, S. (2010). Framework for integrating indigenous and scientific knowledge for disaster risk reduction. Disasters, 34(1), 214-239. 
Moncada, S., Briguglio, L. P., Bambrick, H., \& Kelman, I. (2018). Development and climate change in Small Island Developing States [guest editorial]. International Journal of Climate Change Strategies and Management, 10(2), 214-216.

Mortreux, C., \& Barnett, J. (2009). Climate change, migration and adaptation in Funafuti, Tuvalu. Global Environmental Change, 19(1), 105-112.

Mycoo, M., \& Donovan, M. G. (2017). A blue urban agenda: Adapting to climate change in the coastal cities of Caribbean and Pacific small island developing states. InterAmerican Development Bank.

Myers, N. (1988). Tropical deforestation and climatic change. Environmental Conservation, 15(4), 293-298.

Neef, A., Benge, L., Boruff, B., Pauli, N., Weber, E., \& Varea, R. (2018). Climate adaptation strategies in Fiji: The role of social norms and cultural values. World Development, 107, 125-137.

Noy, I. (2016). Natural disasters in the Pacific Island Countries: New measurements of impacts. Natural Hazards, 84(1), 7-18.

Nunn, P. D. (2007). Holocene sea-level change and human response in Pacific Islands. Earth and Environmental Science Transactions of the Royal Society of Edinburgh, 98(1), 117-125.

Nunn, P. D., Aalbersberg, W., Lata, S., \& Gwilliam, M. (2014). Beyond the core: Community governance for climate-change adaptation in peripheral parts of Pacific Island Countries. Regional Environmental Change, 14(1), 221-235.

Nunn, P. D., \& Mimura, N. (1997). Vulnerability of South Pacific Island nations to sea-level rise. Journal of Coastal Research, Special Issue, 24(Fall), 133-151.

Nunn, P. D., \& Kumar, R. (2018). Understanding climate-human interactions in Small Island Developing States (SIDS) implications for future livelihood sustainability. International Journal of Climate Change Strategies and Management, 10(2), 245-271.

Nurse, L. A., McLean, R. F., Agard, J., Briguglio, L., Duvat-Magnan, V., Pelesikoti, N., . . W Webb, A. (2014). Small islands. In V. R. Barros, C. B. Field, D. J. Dokken, M. D. Mastrandrea, K. J. Mach, T. E. Bilir, ... L. L. White (Eds.), Climate change 2014: Impacts, adaptation, and vulnerability. part B: Regional aspects. contribution of Working Group II to the Fifth Assessment Report of the Intergovernmental Panel on Climate Change (First ed., pp. 1613-1654). Cambridge, UK and New York: Cambridge University Press.

Paavola, J. (2008). Livelihoods, vulnerability and adaptation to climate change in Morogoro, Tanzania. Environmental Science \& Poligy, 11(7), 642-654.

Pelling, M. (2003). The vulnerability of cities: Natural disasters and social resilience. London: Earthscan.

Porter, C. (2008). Examining the impact of idiosyncratic and covariate shocks on Ethiopian households' consumption and income sources. In C. Porter (ed.), Essays on Risk and Poverty (Doctoral dissertation, Oxford University). 
Raymond, C. M., Fazey, I., Reed, M. S., Stringer, L. C., Robinson, G. M., \& Evely, A. C. (2010). Integrating local and scientific knowledge for environmental management. Journal of Environmental Management, 91 (8), 1766-1777.

Riché, B., \& Hammill, A. (2009). Climate related vulnerability and adaptive capacity in Ethiopia's Borana and Somali communities. London: CARE International and IISD.

Ritchie, J., Lewis, J., Nicholls, C. M., \& Ormston, R. (2013). Qualitative research practice: A guide for social science students and researchers. London: Sage.

Roberts, J. L., \& Ibitoye, I. (2012). The big divide: A ten-year report of Small Island Developing States and the millennium development goals. London: Commonwealth Secretariat.

Robledo, C., Clot, N., Hammill, A., \& Riché, B. (2012). The role of forest ecosystems in community-based coping strategies to climate hazards: Three examples from rural areas in Africa. Forest Policy and Economics, 24, 20-28.

Schipper, E. L. F. (2007). Climate change adaptation and development: Exploring the linkages. Tyndall Centre for Climate Change research working paper, 107

Scoones, I. (1998). Sustainable rural livelihoods: A framework for analysis. IDS working paper 72. Brighton: IDS.

Sheil, D., Puri, R., Wan, M., Basuki, I., Heist, M. v., Liswanti, N., . . Samsoedin, I. (2006). Recognizing local people's priorities for tropical forest biodiversity. AMBIO: A Journal of the Human Environment, 35(1), 17-24.

Sheuya, S. A. (2009). Urban poverty and housing transformations in informal settlements: The case of Dar-es-salaam, Tanzania. International Development Planning Review, 31(1), 81-108.

Smit, B., \& Wandel, J. (2006). Adaptation, adaptive capacity and vulnerability. Global Environmental Change, 16(3), 282-292.

Stejskal, N., \& Fernandes, M. (2006). Climate change, vulnerable communities and adaptation - Report on Nicaragua testing. Berne: IUCN, IISD, SEI-B and Intercooperation.

Stephens, M., Lowry, J. H., \& Ram, A. R. (2018). Location-based environmental factors contributing to rainfall-triggered debris flows in the Ba River catchment, northwest Viti Levu Island, Fiji. Landslides, 15(1), 145-159.

Strauss, A., \& Corbin, J. M. (1990). Basics of qualitative research: Grounded theory procedures and techniques. London: Sage.

Sultana, P., \& Thompson, P. (2004). Methods of consensus building for community-based fisheries management in Bangladesh and the Mekong Delta. Agricultural Systems, 82(3), 327-353.

Tacoli, C. (1999). Understanding the opportunities and constraints for low-income groups in the peri-urban interface: The contribution of livelihood frameworks. London: Development Planning Unit, UCL.

Takasaki, Y. (2017). Post-disaster informal risk sharing against illness. World Development, 94, 64-74.

Tourangeau, R., Rips, L. J., \& Rasinski, K. (2000). The psychology of survey response. Cambridge: Cambridge University Press. 
Vogel, C. (1998). Vulnerability and global environmental change. LUCC Newsletter, 3, 15-19.

Walsh, K. J., McBride, J. L., Klotzbach, P. J., Balachandran, S., Camargo, S. J., Holland, G., ... Sobel, A. (2016). Tropical cyclones and climate change. WIREs Climate Change, 7(1), 65-89.

Warrick, O., Aalbersberg, W., Dumaru, P., McNaught, R., \& Teperman, K. (2017). The 'Pacific adaptive capacity analysis framework': Guiding the assessment of adaptive capacity in Pacific Island communities. Regional Environmental Change, 17(4), 1039-1051.

World Bank. (2017). World development indicators. Washington, DC: World Bank Group. 